\title{
A Flavin-dependent Sulfhydryl Oxidase in Bovine Milk†
}

\author{
Jennifer Jaje $\ddagger$, Holly N. Wolcott ${ }^{\ddagger}$, Olajumoke Fadugba $^{\ddagger}$, Diane Cripps $\rrbracket$, Austin J. Yang $\Uparrow, \|$, \\ Ian H. Mather $\S$, and Colin Thorpe ${ }^{*}, \ddagger$ \\ \$Department of Chemistry and Biochemistry, University of Delaware, Newark, Delaware 19716
}

II Greenebaum Cancer Center, University of Maryland, Baltimore, Baltimore, Maryland 21201

IDepartment of Anatomy and Neurobiology, University of Maryland, Baltimore, Baltimore, Maryland 21201

$\S$ Department of Animal and Avian Sciences, the University of Maryland, College Park, Maryland 20742

\begin{abstract}
Both metal and flavin-dependent sulfhydryl oxidases catalyze the net generation of disulfide bonds with the reduction of oxygen to hydrogen peroxide. The first mammalian sulfhydryl oxidase to be described was an iron-dependent enzyme isolated from bovine milk whey. This protein was reported to contain 0.5 atoms of iron per $89 \mathrm{kDa}$ subunit and to be completely inhibited by ethylenediaminetetraacetate (EDTA). However the present work shows that a soluble $62 \mathrm{kDa}$ FADlinked and EDTA-insensitive sulfhydryl oxidase apparently constitutes the dominant disulfide bondgenerating activity in skim milk. Unlike the metalloenzyme, the flavoprotein is not associated tightly with skim milk membranes. Sequencing of the purified bovine enzyme $(<70 \%$ coverage $)$ showed it to be a member of the Quiescin-sulfhydryl oxidase (QSOX) family. Consistent with its solubility, this bovine QSOX1 paralog lacks the C-terminal transmembrane span of the long form of these proteins. Bovine milk QSOX1 is highly active towards reduced RNase and with the model substrate dithiothreitol. The significance of these new findings is discussed in relation to the earlier reports of metal-dependent sulfhydryl oxidases.
\end{abstract}

Both metal- and flavin-dependent sulfhydryl oxidases catalyze disulfide bond formation at the expense of molecular oxygen:

$$
2 \mathrm{R}-\mathrm{SH}+\mathrm{O}_{2} \rightarrow \mathrm{R}-\mathrm{S}-\mathrm{S}-\mathrm{R}+\mathrm{H}_{2} \mathrm{O}_{2}
$$

In the former category, copper-dependent oxidases from skin (1,2) kidney (3) and antibodyproducing tumor tissue (4) have been described, although the metal dependence of the skin enzyme is now in doubt (5). Swaisgood and colleagues, following earlier work by Kiermeier and coworkers (6-9), have conducted a range of studies on a sulfhydryl oxidase that they isolated from bovine milk. These investigations have included: enzyme specificity (10-14), steady state kinetics (15), together with analysis of molecular weight $(10,16,17)$, amino acid composition and metal content $(10,17)$. Their $89 \mathrm{kDa}$ milk enzyme contained 0.5 equivalents of iron per subunit (10) and was completely inhibited by 1 mM EDTA $(10,17)$. Activity was regained upon the addition of iron and, to a lesser extent with divalent copper and manganese (44 and $33 \%$ of the recovery with iron respectively) $(10,17)$. These data suggest a metal binding site of considerable accommodation. Alternative purification methods of the enzyme have been presented by the same laboratory $(16,18-20)$. The enzyme has yet to be sequenced or cloned.

\footnotetext{
${ }^{\dagger}$ This work was supported in part by NIH GM26643 (C.T.), MH59786 and AG25323 (A.J.Y), by the Cigarette Restitution Fund (DC), and USDA grant 2006-35206-16820 (I.H.M.).

*Author for correspondence. Telephone: (302) 831-2689. Fax: (302) 831-6335. E-mail: cthorpe@udel.edu
} 
An important contribution of this pioneering work was the suggestion that the sulfhydryl oxidases may play significant roles in oxidative protein folding in mammals $(10,12,17,21)$.

The second mammalian sulfhydryl oxidase to be purified was isolated from rat seminal vesicles by Kistler and colleagues $(22,23)$ and was later found to be a member of a newly recognized family of flavoenzymes termed Quiescin-sulfhydryl oxidases $\left({ }^{1} \mathrm{QSOX}\right)(24,25)$. Vertebrates have two QSOX paralogs (26-29) of which QSOX1 is the only one that has received detailed enzymological scrutiny. Two alternate splice forms of QSOX1 exist: a long form $(\sim 80 \mathrm{kDa})$ which retains a single transmembrane span at its $\mathrm{C}$-terminus, and a shorter, soluble, form $(\sim$ $63 \mathrm{kDa})$ truncated before this feature $(26,28,30)$. QSOX enzymes are particularly associated with cells bearing a heavy secretory load $(26-28,31)$. QSOX has been found extracellularly $(23,25,31-34)$ and in a variety of intracellular locales $(26,28-31,35)$.

Several recent findings raised the possibility that milk might contain QSOX1 in addition to the iron-dependent oxidase described above. First, immunohistochemistry of human mammary tissue using an anti-peptide antibody directed against residues 494-507 of human QSOX1 (Ref Seq NP_002817) showed strong staining of the apical caps of breast secretory epithelial cells (28). Second, an expression profiling database queried for QSOX1 suggested marked expression levels in mouse mammary tissue (36). Finally, a SAGE expression database of mouse tissues showed the highest level of QSOX1 was found in lactating mammary gland (37).

We therefore considered the possibility that QSOX might be released from mammary epithelial cells during formation of the skim or cream phases of milk. To estimate the relative contribution of metal- and flavin-dependent sulfhydryl oxidases in milk, we planned to exploit their differential sensitivities to metal chelators. As mentioned earlier, the iron-dependent enzyme was reported to be completely inhibited by EDTA (10) while the flavin-dependent QSOX enzymes from egg white and mouse seminal vesicles are unaffected by this chelating agent $(23,33)$. However, in multiple experiments performed with batches of fresh milk obtained over a two-year period, we found that EDTA had essentially no effect on the sulfhydryl oxidase activity of whole or skim milk. This suggested that the metal-dependent enzyme reported by Swaisgood and colleagues contributed little to the overall sulfhydryl oxidase activity of milk under our assay conditions.

Herein, we report the isolation and characterization of a QSOX1 from bovine milk, and develop a purification procedure that is both robust and reproducible. In addition to providing a potentially useful new source of mammalian QSOX, we hope that this work will encourage renewed investigation of sulfhydryl oxidases whose activity is believed to be metal-dependent.

\author{
${ }^{1}$ Abbreviations: \\ DTNB \\ 5,5'dithiobis(2-nitrobenzoate) \\ DTT \\ dithiothreitol \\ GSH \\ reduced glutathione \\ $\mathbf{K P} \mathbf{i}$ \\ potassium phosphate \\ QSOX \\ flavin-dependent sulfhydryl oxidases homologous to Quiescin Q6
}

SAGE

serial analysis of gene expression 


\section{EXPERIMENTAL PROCEDURES}

\section{Materials}

Most reagents were obtained as described previously (5,33,38-41): 4-Aminoantipyrine and ferrozine were from Sigma, phenol was from Fisher and trishydroxypropylphosphine (THP) was obtained from Calbiochem.

\section{General}

Absorbance and fluorescence instrumentation was as described earlier (40). Concentrations of purified bovine QSOX1 were determined at $458 \mathrm{~nm}$ using an extinction coefficient determined for the corresponding avian enzyme $\left(12.5 \mathrm{mM}^{-1} \mathrm{~cm}^{-1} ;(33)\right.$. Unless otherwise stated, potassium phosphate buffer, pH 7.5, containing $1 \mathrm{mM}$ EDTA, was used. Experiments were performed at $25^{\circ} \mathrm{C}$ unless otherwise noted.

\section{Enzyme assays}

Two procedures were used to assay for sulfhydryl oxidase activity: measurement of oxygen uptake using an oxygen electrode to characterize the kinetic parameters of the purified enzyme (see below), and a simple discontinuous screening assay to handle the large numbers of chromatographic fractions generated during purification of the enzyme. In the latter, aliquots of suitable volume (for example $180 \mu \mathrm{L}$ for the CM52 column in Figure 2) were added to 20 $\mu \mathrm{L}$ of $3 \mathrm{mM}$ DTT in the wells of a 96-well plate. The top of the plate was securely sealed with parafilm to prevent evaporation. The plate was incubated at room temperature, and quenched after $1 \mathrm{~h}$ with $20 \mu \mathrm{L}$ of $10 \mathrm{mM}$ DTNB in $50 \mathrm{mM}$ phosphate buffer containing $1 \mathrm{mM}$ EDTA. Absorbance values were recorded with a Perkin Elmer Fusion plate-reader using a $405 \mathrm{~nm}$ filter. However, sulfhydryl oxidase-containing wells were readily apparent by eye because they showed a decrease, or absence, of the strong yellow background absorbance of the thionitrobenzoate anion. As the purification of sulfhydryl oxidase progressed smaller aliquots were added to the wells, with the balance made up to $180 \mu \mathrm{L}$ with phosphate buffer. Peroxidasecontaining fractions were also identified in 96 well plates. In this case, $200 \mu \mathrm{L}$ of a working solution (containing $2 \mathrm{mM}$ 4-aminoantipyrene (42) and $20 \mathrm{mM}$ phenol in $20 \mathrm{mM} \mathrm{KP}_{\mathrm{i}}$ with 1 mM EDTA at $\mathrm{pH} 7.5$ ) were added to wells containing $5 \mu \mathrm{L}$ of each fraction. The reaction was started by the addition of $10 \mu \mathrm{L}$ of freshly-prepared $0.3 \%$ hydrogen peroxide. Peroxidasecontaining wells showed a deepening wine-red color as the quinoneimine derivative $(510 \mathrm{~nm}$; (42)) was generated.

Oxygen electrode assays were performed at $25{ }^{\circ} \mathrm{C}$ as described previously (33) in either a standard glass chamber with a $2 \mathrm{ml}$ volume, or one modified to accept a $1 \mathrm{~mL}$ volume by the inclusion of a circular depression impressed in the base of the well (sized to accommodate an $8 \times 2 \mathrm{~mm}$ stir bar). Buffers contained $50 \mathrm{mM}$ potassium phosphate, with or without $1 \mathrm{mM}$ EDTA, pH 7.5. For milk samples, assays were initiated by the addition of $5 \mathrm{mM}$ DTT or GSH (concentrated stock solutions of GSH in water were carefully adjusted to $\mathrm{pH} 6.0$ with $\mathrm{KOH}$ ). All thiol substrates were standardized with DTNB before use. Reduced RNase was prepared, characterized and stored, as described earlier (33). Assays were routinely performed in duplicate and typically contained 10-50 $\mathrm{nM}$ sulfhydry oxidase.

\section{Sulfhydryl oxidase purification}

Four liters of whole milk (combined from 8 Holstein cows) were obtained from the University of Delaware farm at the $7 \mathrm{AM}$ milking. The warm milk was transferred to $500 \mathrm{ml}$ bottles and centrifuged at $1060 \mathrm{~g}$ for 20 minutes in a Sorvall RC-5B centrifuge using a fixed-angle GSA rotor. The skim milk was siphoned from the bottles without disturbing the cream layer on the top and sides of the bottle. The volume of skim milk recovered was approximated $3400 \mathrm{ml}$. 
Casein was precipitated by adding about $190 \mathrm{~mL}$ of $1 \mathrm{M} \mathrm{HCl}$ to the stirred skim milk over about $5 \mathrm{~min}$ at room temperature to a final $\mathrm{pH}$ of 4.6. After centrifugation at $4200 \mathrm{~g}$ for $15 \mathrm{~min}$ at $4{ }^{\circ} \mathrm{C}$, the stirred clear yellow acid-whey was returned to $\mathrm{pH} 7.4$ by the addition of $96 \mathrm{~mL}$ of $1 \mathrm{M} \mathrm{KOH} \mathrm{(correspondingly} \mathrm{less} \mathrm{base} \mathrm{is} \mathrm{required} \mathrm{for} \mathrm{this} \mathrm{step} \mathrm{because} \mathrm{of} \mathrm{the} \mathrm{prior} \mathrm{removal} \mathrm{of}$ caseins). The cloudy solution was supplemented with a protease inhibitor cocktail tablet (Roche) and EDTA to a concentration of $1 \mathrm{mM}$. The stirred solution was brought to $65 \%$ saturation in ammonium sulfate at $4{ }^{\circ} \mathrm{C}$ and then left to settle overnight. The majority of the pale yellow supernatant was removed by siphon, and the precipitated material was resuspended in the remaining liquid and recovered by centrifugation ( $20 \mathrm{~min}$ at $4200 \mathrm{~g}$ ). The supernatants were discarded, and the precipitates kept in four centrifuge bottles maintained in the dark at 4 ${ }^{\circ} \mathrm{C}$ until needed.

Table 1 refers to a purification during which one-half of the precipitated protein was used and so the volumes of whole and skim milk have been adjusted accordingly. The precipitate from two bottles was gently resuspended in a minimal volume of $20 \mathrm{mM}$ phosphate buffer, $\mathrm{pH} 6.0$, containing $1 \mathrm{mM}$ EDTA. This suspension $(65 \mathrm{~mL})$ was dialyzed against two $4 \mathrm{~h}$ changes of 1 $\mathrm{L}$ of the same buffer and then overnight against a third $1 \mathrm{~L}$ of buffer supplemented with a protease inhibitor tablet. Stirring was then stopped, allowing a white granular precipitate to settle to the bottom of the dialysis tubing. Incomplete dialysis leads to problems clearing the solution of this precipitate. The supernatants were centrifuged at $2600 \mathrm{~g}$ for $20 \mathrm{~min}$ to remove any additional precipitate, and the straw-colored, opalescent, supernatant (about $105 \mathrm{~mL}$ ) was collected and applied to a $5 \times 24 \mathrm{~cm}$ CM52 cation exchange column (bed volume $350 \mathrm{~mL}$ ) equilibrated in $20 \mathrm{mM}$ phosphate buffer, $\mathrm{pH}$ 6.0, containing 1 mM EDTA. The column was developed with a gradient of $\mathrm{KCl}$ as follows: the low-salt reservoir $(800 \mathrm{~mL}$ of stirred $20 \mathrm{mM}$ buffer) supplied the head of the column at $156 \mathrm{~mL} / \mathrm{h}$ and was replenished at the same flow rate with a solution of $1 \mathrm{M} \mathrm{KCl}$ dissolved in the same buffer. Six-minute fractions were collected and analyzed by UV/VIS spectrum, and small aliquots from each tube were screened for sulfhydryl oxidase and peroxidase activity in a 96-well format. Once zones of sulfhydryl oxidase activity had been identified, they were more accurately quantitated with the oxygen electrode using both GSH and DTT substrates.

Pooled fractions were brought to $40 \%$ saturation with ammonium sulfate and then the solution applied at $1 \mathrm{~mL} / \mathrm{min}$ to a butyl-Sepharose column $(2.5 \times 7.5 \mathrm{~cm})$ equilibrated at room temperature with $40 \%$ saturated ammonium sulfate in $20 \mathrm{mM}$ phosphate buffer, $\mathrm{pH} 7.5$, containing $1 \mathrm{mM}$ EDTA. The top of the column was supplied at $1 \mathrm{~mL} / \mathrm{min}$ from a $50 \mathrm{~mL}$ volume of stirred $40 \%$ ammonium sulfate in $20 \mathrm{mM}$ phosphate that was progressively diluted with ammonium sulfate-free buffer at the same flow rate. Fractions $(6 \mathrm{~mL})$ were collected and screened with the micro-plate assays as described above and by UV/VIS absorbance. Suitable fractions were pooled, concentrated and washed 3-times with $20 \mathrm{mM}$ phosphate buffer, $\mathrm{pH}$ 7.0, containing $1 \mathrm{mM}$ EDTA using a centrifuge ultrafiltration device (Centriprep YM-30).

The concentrated protein $(0.3 \mathrm{~mL})$ was applied to a $0.5 \times 5 \mathrm{~cm}$ Source $30 \mathrm{~S}$ cation exchange column equilibrated with $20 \mathrm{mM}$ phosphate buffer, $\mathrm{pH}$ 7.0, containing $1 \mathrm{mM}$ EDTA. The column was developed at $0.5 \mathrm{~mL} / \mathrm{min}$ in a linearly increasing gradient to $1 \mathrm{M} \mathrm{KCl}$ in $20 \mathrm{mM}$ phosphate buffer formed by an AKTA-FPLC instrument. Fractions $(0.5 \mathrm{~mL})$ were collected and assessed for purity by UV/VIS spectrum and enzymatic activity. Suitable fractions were combined, concentrated, washed with $50 \mathrm{mM}$ phosphate buffer, $\mathrm{pH} 7.5$ containing $1 \mathrm{mM}$ EDTA, and stored at $-80{ }^{\circ} \mathrm{C}$.

\section{Flavin identification}

The purified enzyme (10 $\mu \mathrm{M}$ in $0.1 \mathrm{~mL}$ of $50 \mathrm{mM}$ phosphate buffer, $\mathrm{pH} 7.5,1 \mathrm{mM}$ EDTA in a microcentrifuge tube wrapped with aluminum foil) was placed in a boiling water bath for 5 $\mathrm{min}$. The tube was cooled in ice and then centrifuged. Aliquots of the supernatant $(50 \mu \mathrm{L})$ were 
applied to a C18-reverse phase column developed with a linear acetonitrile gradient (from $100 \%$ of $0.1 \%$ trifluoroacetic acid (TFA) in water to $100 \% 0.1 \%$ TFA in $90 \%$ acetonitrile) over $50 \mathrm{~min}$. Elution profiles were compared with those for riboflavin, FMN and FAD.

\section{Iron analyses}

A series of iron standards $(0-20 \mu \mathrm{M})$ were prepared by diluting $10 \mathrm{mM}$ ferrous ammonium sulfate in degassed distilled water into $50 \mathrm{mM}$ Tris buffer, $\mathrm{pH}$ 7.5. Sulfhydryl oxidase was used in the same buffer at a concentration of $10 \mu \mathrm{M}$. The following procedure is based on that described by Rebouche et al. (43). Aliquots $(30 \mu \mathrm{L})$ of standards, or protein, were thoroughly mixed with an equal volume of $2 \mathrm{M} \mathrm{HCl}$ in $5 \times 60 \mathrm{~mm}$ glass tubes, placed in a boiling water bath for $1 \mathrm{~min}$, cooled and mixed again. A $50 \mu \mathrm{L}$ volume of these solutions were then diluted with $50 \mu \mathrm{L}$ of a ferrozine working solution, which was made by dissolving $0.5 \mathrm{mM}$ ferrozine in $1.5 \mathrm{M}$ sodium acetate and then adding $0.1 \% \mathrm{v} / \mathrm{v} \beta$-mercaptoethanol immediately before use. After $30 \mathrm{~min}$ at room temperature, protein samples were briefly centrifuged to minimize light scattering material and the absorbance at $562 \mathrm{~nm}$ was recorded in self-masking microcells. Samples of Tris buffer without added iron were carried through this procedure and served as blanks.

\section{Iron supplementation experiments}

Purified bovine sulfhydryl oxidase was washed by ultrafiltration into $50 \mathrm{mM}$ Tris buffer at $\mathrm{pH}$ 7.5 without EDTA and then $5 \mu \mathrm{M}$ enzyme was treated at room temperature for a total of 30 min with $10 \mu \mathrm{M}$ ferrous iron added from a degassed solution of ferrous ammonium sulfate in water. Oxygen electrode assays of the oxidase, using $5 \mathrm{mM}$ DTT, were followed 1 and $30 \mathrm{~min}$ after iron treatment and were compared with traces obtained on the addition of either enzyme or ferrous iron alone.

\section{Gel filtration of skim milk fractions}

A $3 \times 68 \mathrm{~cm}$ column of Superdex 200 size exclusion resin was equilibrated at $90 \mathrm{~mL} / \mathrm{h}$ using $50 \mathrm{mM}$ phosphate buffer, $\mathrm{pH} 7.5$, with or without EDTA. Samples $(2 \mathrm{~mL})$ of skim milk were injected and $3 \mathrm{~mL}$ fractions collected for analysis. Eluates were monitored continuously at 700, 450 and $280 \mathrm{~nm}$. The column was standardized using $2 \mathrm{ml}$ of thyroglobulin $(670,000)$, catalase $(250,000)$, aldolase $(158,000)$, bovine serum albumin $(67,000)$, ovalbumin $(43,000)$, and cytochrome c $(12,400 \mathrm{Da})$ at concentrations of approximately $0.5 \mathrm{mg} / \mathrm{ml}$. A linear standard curve $\left(\mathrm{R}^{2}=0.993\right)$ was generated by plotting the logarithm of the molecular weight against the elution time.

\section{Trypsin digestion and LC-MS/MS analysis of digests}

Protein samples were run on a 10\% SDS-PAGE as detailed above. Coomassie-stained protein bands were excised, chopped into approximately $1 \times 1 \mathrm{~mm}$ cubes and placed in a $1.5 \mathrm{~mL}$ polypropylene centrifuge tube. The pieces were covered with methanol and vortexed intermittently for $5 \mathrm{~min}$. Subsequently the following washing steps were performed: with $30 \%$ methanol/70\% water for $5 \mathrm{~min}$; with two washes of water for $10 \mathrm{~min}$; and three washes with $100 \mathrm{mM}$ ammonium bicarbonate $/ 30 \%$ acetonitrile for $10 \mathrm{~min}$. The entire procedure was repeated until the gel pieces were entirely cleared of the dye. A blank piece of gel containing no protein bands served as a control. The gel pieces were then covered with acetonitrile, vortexed for $30 \mathrm{sec}$ and then excess liquid was removed. Samples were dried in a Vacufuge (Eppendorf) and incubated for $60 \mathrm{~min}$ at $56^{\circ} \mathrm{C}$ in a solution of $10 \mathrm{mM}$ trishydroxypropylphosphine in $100 \mathrm{mM} \mathrm{NH}_{4} \mathrm{HCO}_{3}$ solution, followed by centrifugation to aid the removal of excess liquid. The gel pieces were then incubated for $45 \mathrm{~min}$ at room temperature in the dark with $10 \mathrm{mg}$ iodoacetamide in $1 \mathrm{~mL}$ of $100 \mathrm{mM}$ ammonium bicarbonate. The gel pieces were washed with $100 \mathrm{mM}$ ammonium bicarbonate for $15 \mathrm{~min}$ and dehydrated with 
acetonitrile followed by complete drying in a Speed-Vac. The material was rehydrated on ice for $45 \mathrm{~min}$ by adding a sufficient volume of $50 \mathrm{mM}$ ammonium bicarbonate containing $13 \mu \mathrm{g}$ trypsin/mL to just cover the gel. Excess trypsin solution was removed, replaced with $50 \mathrm{mM}$ ammonium bicarbonate, and incubated overnight at $37^{\circ} \mathrm{C}$. The tube was centrifuged briefly and the solution transferred to a clean centrifuge tube. The gel pieces were further incubated for $15 \mathrm{~min}$ at $37^{\circ} \mathrm{C}$ with intermittent vortexing and the supernatant combined with the trypsin digest. This procedure was repeated with ammonium bicarbonate and then with two further washes using 5\% formic acid in 50\% acetonitrile. The combined trypic peptides were vacuumdried and stored at $-80{ }^{\circ} \mathrm{C}$ before analysis.

The trypsin digests of purified proteins were each analyzed twice by liquid chromatographytandem mass spectrometry as follows. The digests were diluted to an approximate concentration of $100 \mathrm{fmol} / \mu \mathrm{L}$ in $0.1 \%$ formic acid and $2 \%$ acetonitrile (solvent $\mathrm{A}$ ). The peptide samples were sampled by a Spark Holland (Emmen, NL) Endurance autosampler using a 10 $\mu \mathrm{L}$ microliter-pickup injection method and separated on a 15-cm C18 capillary column (75 $\mu \mathrm{m}$ internal diameter, $5 \mu \mathrm{m}$ particle size, $300 \AA$ pore size, Micro-Tech Scientific, Vista, CA) over a gradient from $5-40 \%$ solvent B ( $0.1 \%$ formic acid, $95 \%$ acetonitrile) at a flow rate of $400 \mathrm{~nL} / \mathrm{min}$ on a Micro-Tech Scientific XtremeSimple ultra-high pressure splitless nanoflow liquid chromatography system. The eluting peptides were analyzed by a Thermo Scientific (San Jose, CA) LTQ linear ion trap mass spectrometer equipped with a dynamic nanospray probe using an uncoated $10 \mu \mathrm{m}$-ID SilicaTip ${ }^{\mathrm{TM}}$ PicoTip $^{\mathrm{TM}}$ nanospray emitter (New Objective, Woburn, MA), a source voltage of $2.0 \mathrm{kV}$ and a heated capillary temperature of $200{ }^{\circ} \mathrm{C}$. MS and MS/MS spectra were acquired using Xcalibur 1.4 software. Tandem mass spectrometry was performed by selecting the top five ions of each full scan (400-1800 m/z) for MS/MS sequencing, with dynamic exclusion of ions that had been selected three times in 15 seconds for 15 seconds. An MS/MS/MS scan was triggered if, among the three most abundant ions in the MS/MS scan, a neutral loss of 98, 49, or 32.7 Da was detected (corresponding to loss of phosphoric acid on singly, doubly and triply charged precursor ions). Other parameters used for generating MS/MS data were an isolation width of $3.0 \mathrm{~m} / \mathrm{z}$, a collision energy of $24 \%$ (MS/ MS) and 35\% (MS/MS/MS), a minimum MS signal count of 500, a minimum MS/MS signal count of 100, and an activation time of $120 \mathrm{~ms}$ (MS/MS) and $30 \mathrm{~ms}$ (MS/MS/MS).

\section{Mass Spectrometry Data Analysis}

The ipi.BOVIN.v3.04 database was searched against the raw spectral data files using Sorcerer SEQUEST Version 3.3 (SageN, San Jose, CA) with a peptide mass tolerance of $1.5 \mathrm{amu}$ and differential modifications of $\mathrm{M}+15.9949$ and $\mathrm{C}+57.021464$. Prior to the search, NCBI sequence XP_601276 (similar to quiescin [Bos taurus]) was appended to the database, since there are two areas in which this version of the QSOX1 sequence differs from the IPI.bovine.v3.03 version of QSOX1 (IPI00704610). Spectra of matched peptides were examined to ensure that the $\mathrm{b}$ - and y-ions and the major ions in the spectra corresponded.

\section{RESULTS AND DISCUSSION}

\section{Sulfhydryl oxidase activity in skim milk}

Our preliminary data using glutathione as a substrate (see Methods) confirmed that the bulk of sulfhydryl oxidase activity in whole milk was present in the skim milk fraction (not shown). However, we could not reproduce two key findings of the early studies. The first is the substrate specificity pattern shown by un-fractionated skim milk. The earlier work reported that DTT was not a substrate of the milk sulfhydryl oxidase either in skim milk or in a purified form $(13,15,20,44)$. However, under the conditions of Figure 1, DTT is a better substrate than GSH ( $\sim 1.5$-fold) in skim milk. This observation was repeatedly confirmed using several batches of fresh milk collected over a 2 -year period. In our hands, sulfhydryl oxidase activity is present 
at rather low levels in milk, such that one-half of the assay volume in Figure 1 was milk, with the balance made up with phosphate buffer. Control experiments, omitting milk, showed the expected small background oxygen consumption due to non-enzymatic thiol oxidation (not shown).

A more important issue is the effect of the metal chelator, EDTA, on sulfhydryl oxidase activity. We found an insignificant effect on the rate of oxygen consumption with either GSH or DTT (Figure 1). In this experiment, skim milk was exposed to EDTA for approximately $20 \mathrm{~min}$. To evaluate whether longer incubation times would reveal noticeable inhibition, we treated skim milk overnight with $1 \mathrm{mM}$ EDTA before assay. This pretreatment had no significant effect over an untreated control (not shown). Similar data were obtained with partially purified enzyme prepared in the absence of EDTA (not shown). In sum, we could find no evidence for an effect of EDTA on the activity of skim milk sulfhydryl oxidase.

\section{Purification of milk sulfhydryl oxidase}

For the reasons mentioned above we decided to develop a new purification scheme for bovine milk sulfhydryl oxidase (Table 1), rather than follow the original method or its subsequent modifications $(10,16,18-20,45)$. Because our results are so different from the earlier work, key chromatographic separations are documented in Figures 2 and 3. In our procedure, whey was prepared by precipitating caseins from stirred skim milk at room temperature by adding $1 \mathrm{M}$ $\mathrm{HCl}$ until the $\mathrm{pH}$ reached 4.6 (see Methods). The whey was recovered from the casein precipitate by centrifugation at $4{ }^{\circ} \mathrm{C}$ and then the supernatant was brought to $\mathrm{pH} 7.4$ by the addition of $1 \mathrm{M} \mathrm{KOH}$. It should be noted that EDTA (at $1 \mathrm{mM}$ ) interferes with the acid precipitation of casein and so was only added after the voluminous granular precipitate had been removed. Further, in our hands, the alternative procedure to precipitate casein using chymosin $(10,16,45)$ resulted in lower recovery of activity (not shown).

The neutralized whey, now containing $1 \mathrm{mM}$ EDTA and a protease inhibitor cocktail, was brought to $65 \%$ saturation with ammonium sulfate, and the precipitate collected by centrifugation. Resuspension of this material in phosphate buffer followed by extensive dialysis at $\mathrm{pH} 6.0$ gave an opalescent fraction containing the bulk of sulfhydryl oxidase activity (Table 1). Instead of the initial gel filtration step adopted previously (10), we wanted to exploit a robust high-capacity procedure early in the purification procedure. To this end, we found that cation-exchange chromatography at $\mathrm{pH} 6.0$ provided significant purification of the sulfhydryl oxidase activity (Figure 2; Table 1).

Strongly opalescent fractions emerged first from the CM52 cation-exchange column. These lipid-rich aggregates could be sedimented at $20,000 \mathrm{~g}\left(2 \mathrm{~h}, 4{ }^{\circ} \mathrm{C}\right)$ and were shown by transmission electron microscopy to be a heterogenous mixture of membrane fragments and vesicles (Supplementary Figure S1). Importantly, this light-scattering material contained no detectable sulfhydryl oxidase activity (Figure 2). The column was developed with a gradient of $\mathrm{KCl}$ leading to the emergence of two overlapping bands of sulfhydryl oxidase activity, with $10 \%$ of the activity in fraction "A" and 90\% in fraction "B" (Figure 2). To provide an independent benchmark for this key chromatographic step, we also show the elution profile for lactoperoxidase, a well-known peroxidase found in milk. As expected, the Soret absorbance band (maximal at $415 \mathrm{~nm}$ ) and the peroxidase activity (Figure 2) superimposed.

Part of the minor sulfhydryl oxidase activity in fraction A may reflect the ability of hemedependent peroxidases, including bovine lactoperoxidase, to catalyze the oxidation of thiols, including GSH and DTT (46):

$$
2 \mathrm{R}-\mathrm{SH}+\mathrm{O}_{2} \rightarrow \mathrm{R}-\mathrm{S}-\mathrm{S}-\mathrm{R}+\mathrm{H}_{2} \mathrm{O}_{2}
$$


However the apparent sulfhydryl oxidase activity (with either DTT or GSH) of fraction A does not exactly superimpose with the lactoperoxidase peak (Figure 2). We leave this issue, and the previous suggestion that milk sulfhydryl oxidase and lactoperoxidase interact (47), for further work. The bulk of the sulfhydryl oxidase activity was found in fraction B. Fractions 47-51 were pooled, adjusted to $\mathrm{pH} 7.5$, brought to $40 \%$ saturation (at $25^{\circ} \mathrm{C}$ ) in ammonium sulfate, and applied to a butyl-Sepharose hydrophobic interaction column. This separation was performed at $22{ }^{\circ} \mathrm{C}$ : the chromatographic resolution was noticeably inferior at $4{ }^{\circ} \mathrm{C}$. The sulfhydryl oxidase-containing fractions absorbed to the top of the butyl-Sepharose gel as a pale yellow-orange band and were eluted with a decreasing gradient of ammonium sulfate. The first colored band to emerge was a pink species whose visible spectrum (Figure 3, fraction 16) and apparent molecular weight on SDS-PAGE (ca. $81 \mathrm{kDa}$ ) matched an authentic sample of lactoferrin. Next, came an orange-brown band showing a distinct Soret peak (fraction 19; Figure 3), which was identified as lactoperoxidase. Finally, the sulfhydryl oxidase activity was associated with a yellow band, with the spectrum shown in Figure 3 (fraction 22).

Sulfhydryl oxidase-containing fractions were pooled and subjected to a second cationexchange separation using Source $30 \mathrm{~S}$ resin at $\mathrm{pH}$ 7.0. Following this step, the combined fractions containing sulfhydryl oxidase activity had a UV/VIS spectrum showing an unresolved flavin envelope with maxima at 458 and $365 \mathrm{~nm}$ (Figure 4). At this stage the enzyme separated as essentially a single band of protein on SDS-PAGE, with a molecular weight corresponding to $\sim 62 \mathrm{kDa}$ (see inset Figure 4). A sample of the protein was boiled and the released flavin shown to be FAD by comparison with the elution times of riboflavin, FMN and FAD on reverse phase HPLC (see Methods).

Table 1 summarizes the purification developed here: a greater than 15,000-fold purification is required to obtain substantially pure protein. Previously a 3,000-fold to 4,830-fold purification $(10,16,45)$ from skim milk was reported to yield a single band on SDS-PAGE with an apparent molecular weight of about $89 \mathrm{kDa}(10,16,19)$. A major contaminant we observed after the CM52 step showed an apparent molecular weight of about $81 \mathrm{kDa}$ (a comparison of the purities after each column step is presented in Supplemental Figure S2). Sequencing of tryptic peptides showed that this impurity was bovine lactoferrin: an abundant milk protein with the ability to bind up to two iron atoms per monomer (see later (48-50).

\section{Iron content of milk sulfhydryl oxidase}

We next considered experiments in which ferrous iron was added to the purified sulfhydryl oxidase solutions. In the previous study (10), sulfhydryl oxidase preparations, in phosphate buffer, were treated with EDTA and then dialyzed against $1 \mu \mathrm{M}$ ferrous sulfate before assessing enzyme activity in $50 \mathrm{mM}$ phosphate buffer $\mathrm{pH}$ 7.0. This protocol raises several issues. First, the solubility product of ferrous phosphate is very low $\left(\sim 10^{-32}\right.$; (51)) suggesting that an almost stoichiometric depletion of iron from solution would occur. Second, ferrous salts rapidly oxidize in neutral aerobic solutions yielding insoluble ferric hydroxide aggregates (52). Finally, the use of a vibrating platinum electrode for oxygen concentration measurements (10) is of some concern. Platinum surfaces are prone to thiol-mediated passivation (from glutathione and other substrates) unless coated with cellulose acetate or collodion (53). Further, added transition metals can promote an electrochemical response at a bare platinum electrode that may interfere with oxygen quantitation.

Iron analysis of our purified flavoenzyme using ferrozine (see Methods) showed minor levels of iron (0.04 +/- 0.02) iron atoms/per monomer). To evaluate the effect of added iron, we incubated $5 \mu \mathrm{M}$ enzyme for 30 min with $10 \mu \mathrm{M}$ of ferrous ammonium sulfate in Tris buffer $(50 \mathrm{mM}, \mathrm{pH} 7.5$; in the absence of EDTA). Assays were then conducted in the same Tris buffer. No significant change in activity, over controls without added metal, was obtained in duplicate experiments using DTT as a substrate (data not shown). In aggregate, the UV-VIS spectrum 
of the purified protein (Figure 4), the presence of only small levels of iron in the enzyme (consistent with adventitious metal binding), the absence of stimulation when ferrous iron is added, and the lack of EDTA inhibition, indicate that the activity we have followed from skim milk to essential purity is an iron-independent flavin-containing oxidase. A final piece of evidence is provided in the next section: the milk enzyme isolated here is a member of the QSOX family of flavin-dependent sulfhydryl oxidases. These enzymes have been already demonstrated to bind metal ions adventitiously, but are not themselves dependent on transition metals for their biological activity (5).

\section{Sequence of the flavin-dependent sulfhydryl oxidase}

The $62 \mathrm{kDa}$ band was excised from SDS-PAGE gels (e.g. inset Figure 4), destained, and the protein digested with trypsin (See Methods). A search of the spectral data obtained from LCMS/MS analysis of the flavoprotein band against the ipi_BOVIN_v_3_04 database determined that the protein was QSOX1 ("similar to quiescin Q6 isoform a": IPI00704610). One contaminating protein, heparanase, was also identified at very low abundance (about 1\%): an average of 9218 QSOX peptide spectra were identified in each run, in comparison to only 122 heparanase spectra. Details of the mass spectral analysis are presented in Supplemental materials (Supplementary Tables S1 and S2). An indication of the quality of the MS sequencing data is presented for the tryptic peptide NNEEYLALIFEK in Figure 5.

Since the available database sequences for bovine QSOX1 contained discrepancies, we compared these to other mammalian QSOX1 sequences (not shown) and to the substantial sequence coverage that our MS/MS analysis affords. In this way we can report a reliable consensus sequence for bovine QSOX1 in Figure 6. Supporting information for this sequence is presented in Supplemental Materials. Clearly the bovine QSOX secreted in milk is the lower molecular weight short form lacking the weakly conserved variable C-terminal stretch including the single transmembrane spanning region (Figure 6). The bovine sulfhydryl oxidase is clearly QSOX1 and not QSOX2: a comparison of pairwise sequence identities between the short-form paralogs of human, bovine, mouse and avian QSOX is presented in Table 2. Milk QSOX has all of the sequence elements previously believed to be catalytically important in the avian QSOX1 enzyme (26-28,54). In particular, it has the three conserved CxxC motifs found in all QSOXs (highlighted in red), together with two thioredoxin domains (in blue) and an Erv/ ALR flavin binding domain (in green).

We wished to also identity the $81 \mathrm{kDa}$ contaminant that was prominent at earlier stages of the purification. MS/MS sequencing showed this protein to be lactoferrin (gi:2781197; 84\% sequence coverage from 150 unique peptides; Supplemental Table S3). Wilcox et al. (55) have reported the association of a sulfhydryl oxidase activity with CD36, an $85 \mathrm{kDa}$ membrane glycoprotein secreted in association with bovine fat globule and skim milk membranes (56). While we did not observe this protein in our purification procedure, perhaps QSOX1 can associate non-covalently with multiple milk components under certain conditions. Indeed, evidence that the flavin-linked sulfhydryl oxidase is found in multimeric assemblies in untreated skim milk is presented below.

\section{Bovine sulfhydryl oxidase does not tightly associate with skim milk membranes in milk}

It has previously been stated that "Bovine milk sulfhydryl oxidase (SOX) is a metalloglycoprotein that resides as an integral enzyme in the plasma membrane of mammary secretory cells" (16). In earlier studies, the source of sulfhydryl oxidase was "skim milk membranes", which are often concentrated from milk whey by precipitation using $50 \%$ saturated ammonium sulfate $(20,57)$. This precipitate contains membrane vesicles, but it will also logically include proteins precipitated by salting-out that are not necessarily originally membrane-associated. Two observations show that the sulfhydryl oxidase isolated in this work 
is not tightly associated with skim milk membranes. First, membrane vesicles are not retained on cation exchange chromatography (Figure 2 and Supplemental Figure S1). These fractions contained no detectable sulfhydryl oxidase activity using either glutathione or DTT (Figure 2). It is important to note that the amounts of ammonium sulfate used to precipitate whey proteins differ between the present and earlier purification procedures. We brought acid whey to $65 \%$ saturation in ammonium sulfate, whereas the earlier investigators used whey prepared by coagulating the caseins with chymosin and precipitating protein from the cleared whey with ammonium sulfate at 50\% saturation (20). Major differences in the outcome of these procedures are therefore plausible. However both methods concentrate whey protein with membrane fragments using ammonium sulfate precipitation.

To address the fundamental question of whether QSOX1 associates with skim milk membrane fragments in untreated skim milk, we used a large size-exclusion column of Superdex 200 (see Methods). Elution from this calibrated column was monitored by absorbance at $280 \mathrm{~nm}$, by light scattering (assessed at $700 \mathrm{~nm}$ ) and by activity measurements for sulfhydryl oxidase and lactoperoxidase (to serve as a landmark). Opalescent fractions containing membranes eluted in the void volume (at $\sim 130 \mathrm{~mL}$ ), considerably in advance of the single peak of QSOX activity centered at $165 \mathrm{~mL}$. Prior calibration of the column with proteins from 670 to $12 \mathrm{kDa}$ showed that bovine QSOX activity in skim milk eluted with an apparent MW of $354 \mathrm{kDa}$. This is in marked contrast to the purified protein, which eluted as a monomer with an apparent molecular weight of about $77 \mathrm{kDa}$ (not shown). The reason for these size differences is not clear and beyond the scope of this present investigation. The gel-filtration elution profile of skim milk in Figure 7 was essentially identical when samples were separated in the absence of EDTA (not shown).

Besides the gel-filtration data, there is another reason to believe that QSOX1 is not tightly associated with skim milk membranes. These membranes are often prepared on a small scale by sedimentation of skim milk at $100,000 \mathrm{~g}$ for $1-2 \mathrm{~h}(58,59)$. When we centrifuged fresh skim milk at $100,000 \mathrm{~g}$ for $2 \mathrm{~h}$, we obtained the expected compact white casein precipitate, overlaid with a fluffy layer of skim milk membranes. Assays of the resuspended fluffy layer, and the supernatant fractions, showed that essentially all $(<90 \%)$ of the SOX activity was in the supernatant (not shown). Similarly, Isaac observed no loss of SOX activity in supernatants obtained after human skim milk was centrifuged for $90 \mathrm{~min}$ at 100,000 $\mathrm{g}(60)$. In summary, we conclude that the QSOX activity in untreated skim milk is not tightly associated with the structures traditionally regarded as skim milk membranes.

\section{Catalytic activity of bovine milk QSOX}

The $\mathrm{k}_{\mathrm{cat}} / \mathrm{K}_{\mathrm{m}}$ values for the oxidation of DTT, glutathione and reduced RNase by bovine QSOX1 are marginally higher than those of their egg white counterpart (Table 3). Like the egg white enzyme, bovine QSOX1 oxidizes reduced RNase efficiently with a $\mathrm{K}_{\mathrm{m}}$ per thiol of $60 \mu \mathrm{M}$. Glutathione is a relatively poor substrate of the milk enzyme, with a $\mathrm{K}_{\mathrm{m}}$ of $4.9 \mathrm{mM}$. This value is some 4-fold lower than the avian enzyme (33). The general catalytic similarities between the two enzymes (Table 3 ) suggest that insights gained from the avian enzyme will be applicable to the bovine oxidase.

\section{Conclusions}

This is the first report of the purification of a flavin-linked sulfhydryl oxidase from milk. The finding of QSOX1 in milk is consistent with expression and SAGE databases in human and mouse mammary tissue and the immunohistochemical studies of human breast tissue using an anti-QSOX1 peptide antibody $(28,36,37)$. 
QSOX enzymes have been localized to the endoplasmic reticulum, Golgi complex, secretory granules, and the plasma membrane $(26,28,29,31,61,62)$ and are also secreted from cells. For example, QSOX1 appears in rat seminal vesicle secretions $(23,25,30,63)$, human tears $(54)$, bovine blood (34), avian egg white $(24,33)$ and as shown here, in bovine milk. The reasons for the secretion of QSOX enzymes into such diverse biological fluids are unclear. One possibility is that QSOX is secreted alongside some of the disulfide bridged proteins it has helped to generate because it has additional extracellular roles - possibly disulfide generation, in the formation of hydrogen peroxide for antimicrobial effects $(23,25,26)$, or for signaling $(27,64)$. Human milk sulfhydryl oxidase is rather stable at $\mathrm{pH} 2.5$ and is resistant to degradation by pepsin, trypsin and chymotrypsin. Consequently, it has been suggested that it may function in protecting the gastrointestinal tracts of newborns as a component of the innate immune system (65).

We were unable to verify the existence of significant additional sulfhydryl oxidase activities in bovine milk, including the membrane-bound iron-binding oxidase described by Swaisgood and coworkers. We can explain neither the EDTA inhibition of this activity, nor its partial reconstitution by the addition of a variety of redox-active transition metals. Nor can we reconcile why the QSOX1 activity, which we have purified, is freely soluble, whereas the putative iron-binding enzyme is apparently associated with membranes in skim milk. As documented above, the two preparations also have markedly different substrate specificities. In addition, a 3,000- to 4,830-fold purification of the iron-binding enzyme from skim milk yielded an apparently homogeneous preparation, whereas the QSOX1 enzyme, required an over 15,000-fold purification from the same starting material. Until the final stages of purification, lactoferrin was a persistent contaminant. Thus it is possible that some of the properties previously associated with the iron-dependent oxidase might have reflected the presence of lactoferrin.

Parallel uncertainties extend to a copper-dependent sulfhydryl oxidase from mammalian skin (1). The skin oxidase was also reported to be completely inhibited by EDTA and reactivated by added copper ions. Yet when a skin sulfhydryl oxidase was cloned, it was found to be the flavoenzyme, QSOX1 (66). While we cannot exclude the possibility that there are both flavin and metal-dependent oxidases in skin, we have found that both holo- and FAD-free QSOX proteins, with their clusters of $\mathrm{CxxC}$ motifs, are able to efficiently bind transition metals including zinc and copper (5). In our hands, copper-binding inhibits, rather than stimulates, sulfhydryl oxidase activity (5). Finally, there are at least three additional reports of copperdependent sulfhydryl oxidases that are inactivated by EDTA and reactivated by the addition of $\mathrm{Cu}^{2+}$ ions: enzymes present at the basal lateral surfaces of the small intestine (3), kidney (3), and an activity partially purified from antibody-producing tumors (4). Given the burgeoning interest in oxidative protein folding, a reinvestigation of these poorly understood metalloenzyme sulfhydryl oxidases is clearly warranted.

\section{Supplementary Material}

Refer to Web version on PubMed Central for supplementary material.

\section{ACKNOWLEDGMENTS}

We thank Mr. Ron Gouge and the University of Delaware Farm personnel for their generous help with collecting unprocessed fresh milk and Vamsi Kodali for helpful discussions.

\section{REFERENCES}

1. Yamada H. Localization in skin, activation and reaction mechanisms of skin sulfhydryl oxidase. Nippon Hifuka Gakkai Zasshi 1989;99:861-869. [PubMed: 2585780] 
2. Goldsmith L. Sulfhydryl Oxidase from Rat Skin. Methods Enzymol 1987;143:510-515. [PubMed: 3657562]

3. Lash LH, Jones DP. Characterization of the membrane-associated thiol oxidase activity of rat smallintestinal epithelium. Arch Biochem. Biophys 1983;225:344-352. [PubMed: 6614926]

4. Roth RA, Koshland ME. Identification of a lymphocyte enzyme that catalyzes pentamer immunoglobulin M assembly. J. Biol. Chem 1981;256:4633-4639. [PubMed: 7217104]

5. Brohawn SG, Rudik I, Thorpe C. Avian sulfhydryl oxidase is not a metalloenzyme: adventitious binding of divalent metal ions to the enzyme. Biochemistry 2003;42:11074-11082. [PubMed: 12974644]

6. Kiermeier F, Ranfft K. About Some Characteristics of Sulfhydryloxidase in Milk. Zeitschrift Lebensm. Unters. Forsch 1970;143:11-15.

7. Kiermeier F, Petz E. A sulfhydryl group-oxidizing enzyme in milk. I. isolation and characterization of the enzyme. Z. Lebensm. Unters. Forsch 1967;132:342-352.

8. Kiermeier F, Petz E. A Sulfhydryl group-oxidizing Enzyme in milk: II Influence of heating on milk and whey. Z. Lebensm. Unters. Forsch 1967;134:97-102.

9. Kiermeier F, Petz E. A Sulfhydryl group-oxidizing Enzyme in milk: III. Effect of heating temperature and heating time. Z. Lebensm. Unters. Forsch 1967;134:149-156.

10. Janolino VG, Swaisgood HE. Isolation and characterization of sulfhydryl oxidase from bovine milk. J. Biol. Chem 1975;250:2532-2538. [PubMed: 1123323]

11. Janolino VG, Swaisgood HE, Horton HR. Renaturation of soluble and immobilized ribonuclease: are the polypeptide folding pathways for structure formation the same for soluble proteins and for proteins associated with a surface? J. Appl. Biochem 1985;7:33-37. [PubMed: 4008393]

12. Janolino VG, Swaisgood HE. Sulfhydryl oxidase-catalyzed formation of disulfide bonds in reduced ribonuclease. Arch. Biochem. Biophys 1987;258:265-271. [PubMed: 3662539]

13. Janolino VG, Swaisgood HE. A comparison of sulfhydryl oxidase from bovine milk and Aspergillus niger. Milchwissenschaft 1992;47:143-146.

14. Schmelzer CH, Swaisgood HE, Horton HR. Glycylglycyl-L-cysteine as a substrate for renal sulfhydryl oxidase (glutathione oxidase). Biochimica et Biophysica Acta 1985;827:140-143. [PubMed: 3967034]

15. Sliwkowski MX, Swaisgood HE, Clare DA, Horton HR. Kinetic mechanism and specificity of bovine milk sulphydryl oxidase. Biochem. J 1984;220:51-55. [PubMed: 6743273]

16. Janolino VG, Swaisgood HE. Purification of Reactive Sulfhydryl Enzymes by Bioselective Adsorption on Monomeric Avidin - Purification of Sulfhydryl Oxidase. J. Food Biochem 1993;16:389-399.

17. Janolino, VG. Ph.D. Dissertation, Department of Food Science. North Carolina State University; Raleigh: 1973.p. 85

18. Sliwkowski MX, Sliwkowski MB, Swaisgood HE, Horton HR. Isolation and Characterization of Sulfhydryl Oxidase by Covalent Chromatography on Cysteinylsuccinamidopropyl-Glass. Federation Proceedings 1981;40:1723-1723.

19. Janolino VG, Swaisgood HE. Homogeneity of Sulfhydryl Oxidase Preparations Obtained by Transient Covalent Affinity-Chromatography. J. Dairy Science 1990;73:308-313.

20. Swaisgood H, Janolino V. Mammalian sulfhydryl oxidase. Food Science and Technology 2003;122:539-546.

21. Janolino VG, Sliwkowski MX, Swaisgood HE, Horton HR. Catalytic effect of sulfhydryl oxidase on the formation of three-dimensional structure in chymotrypsinogen A. Arch. Biochem. Biophys 1978;191:269-277. [PubMed: 736566]

22. Ostrowski MC, Kistler WS, Williams-Ashman HG. A flavoprotein responsible for the intense sulfhydryl oxidase activity of rat seminal vesicle secretion. Biochem. Biophy. Res. Comm 1979;87:171-176.

23. Ostrowski MC, Kistler WS. Properties of a flavoprotein sulfhydryl oxidase from rat seminal vesicle secretion. Biochemistry 1980;19:2639-2645. [PubMed: 7397095] 
24. Hoober KL, Glynn NM, Burnside J, Coppock DL, Thorpe C. Homology between egg white sulfhydryl oxidase and quiescin Q6 defines a new class of flavin-linked sulfhydryl oxidases. J. Biol. Chem 1999;274:31759-31762. [PubMed: 10542195]

25. Benayoun B, Esnard-Fève A, Castella S, Courty Y, Esnard F. Rat seminal vesicle FAD-dependent sulfhydryl oxidase:biochemical characterization and molecular cloning of a member of the new sulfhydryl oxidase/quiescin Q6 gene family. J. Biol. Chem 2001;276:13830-13837. [PubMed: 11278790]

26. Coppock DL, Thorpe C. Multidomain flavin-dependent sulfhydryl oxidases. Antioxid. Redox Signal 2006;8:300-311. [PubMed: 16677076]

27. Thorpe C, Coppock DL. Generating disulfides in multicellular organisms: Emerging roles for a new flavoprotein family. J. Biol. Chem 2007;282:13929-13933. [PubMed: 17353193]

28. Thorpe C, Hoober K, Raje S, Glynn N, Burnside J, Turi G, Coppock D. Sulfhydryl oxidases: emerging catalysts of protein disulfide bond formation in eukaryotes. Arch. Biochem. Biophys 2002;405:112. [PubMed: 12176051]

29. Wittke I, Wiedemeyer R, Pillmann A, Savelyeva L, Westermann F, Schwab M. Neuroblastomaderived sulfhydryl oxidase, a new member of the sulfhydryl oxidase/Quiescin6 family, regulates sensitization to interferon gamma-induced cell death in human neuroblastoma cells. Cancer Res 2003;63:7742-7752. [PubMed: 14633699]

30. Radom J, Colin D, Thiebault F, Dognin-Bergeret M, Mairet-Coello G, Esnard-Feve A, Fellmann D, Jouvenot M. Identification and expression of a new splicing variant of FAD-sulfhydryl oxidase in adult rat brain. Biochim. Biophys. Acta 2006;1759:225-233. [PubMed: 16806532]

31. Tury A, Mairet-Coello G, Esnard-Feve A, Benayoun B, Risold PY, Griffond B, Fellmann D. Cellspecific localization of the sulphydryl oxidase QSOX in rat peripheral tissues. Cell Tissue Res 2006;323:91-103. [PubMed: 16160860]

32. Coppock DL, Kopman C, Scandalis S, Gillerman S. Preferential gene expression in quiescent human lung fibroblasts. Cell Growth Differ 1993;4:483-493. [PubMed: 8396966]

33. Hoober KL, Joneja B, White HB III, Thorpe C. A Sulfhydryl Oxidase from Chicken Egg White. J. Biol. Chem 1996;271:30510-30516. [PubMed: 8940019]

34. Zanata SM, Luvizon AC, Batista DF, Ikegami CM, Pedrosa FO, Souza EM, Chaves DF, Caron LF, Pelizzari JV, Laurindo FR, Nakao LS. High levels of active quiescin Q6 sulfhydryl oxidase (QSOX) are selectively present in fetal serum. Redox Rep 2005;10:319-323. [PubMed: 16438804]

35. Tury A, Mairet-Coello G, Poncet F, Jacquemard C, Risold PY, Fellmann D, Griffond B. QSOX sulfhydryl oxidase in rat adenohypophysis: localization and regulation by estrogens. J. Endocrinol 2004;183:353-363. [PubMed: 15531723]

36. Su, AI.; Wiltshire, T.; Batalov, S.; Lapp, H.; Ching, KA.; Block, D.; Zhang, J.; Soden, R.; Hayakawa, M.; Kreiman, G.; Cooke, MP.; Walker, JR.; Hogenesch, JB. A gene atlas of the mouse and human protein-encoding transcriptomes; Proc. Natl. Acad. Sci. U S A. 2004. p.

6062-7.http://symatlas.gnf.org/SymAtlas/

37. The Cancer Genome Anatomy project. 2006.

http://cgap.nci.nih.gov/SAGE/MEMatrix?ORG=Mm\&METHOD=SS10,LS10\&FORMAT=html\&TAG=AAGAAAAAGC 8

38. Hoober KL, Thorpe C. Egg white sulfhydryl oxidase: Kinetic mechanism of the catalysis of disulfide bond formation. Biochemistry 1999;38:3211-3217. [PubMed: 10074377]

39. Hoober KL, Sheasley SS, Gilbert HF, Thorpe C. Sulfhydryl oxidase from egg white: a facile catalyst for disulfide bond formation in proteins and peptides. J. Biol. Chem 1999;274:22147-22150. [PubMed: 10428777]

40. Farrell SR, Thorpe C. Augmenter of liver regeneration: a flavin dependent sulfhydryl oxidase with cytochrome C reductase activity. Biochemistry 2005;44:1532-1541. [PubMed: 15683237]

41. Wang W, Winther JR, Thorpe C. Erv2p: characterization of the redox behavior of a yeast sulfhydryl oxidase. Biochemistry 2007;46:3246-3254. [PubMed: 17298084]

42. Trinder P. Determination of Blood Glucose Using an Oxidase-Peroxidase System with a NonCarcinogenic Chromogen. J. Clin. Path 1969;22:158-161. [PubMed: 5776547]

43. Rebouche CJ, Wilcox CL, Widness JA. Microanalysis of non-heme iron in animal tissues. J. Biochem. Biophys. Meth 2004;58:239-251. [PubMed: 15026210] 
44. Swaisgood HE, Horton HR. Sulfhydryl oxidase: oxidation of sulphydryl groups and the formation of three-dimensional structure in proteins. Ciba Found. Symp 1980;72:205-222. [PubMed: 398763]

45. Sliwkowski MX, Sliwkowski MB, Horton HR, Swaisgood HE. Resolution of sulphydryl oxidase from gamma-glutamyltransferase in bovine milk by covalent chromatography on cysteinylsuccinamidopropyl-glass. Biochem. J 1983;209:731-739. [PubMed: 6135413]

46. Olsen J, Davis L. The oxidation of dithiothreitol by peroxidases and oxygen. Biochim. Biophys. Acta 1976;445:324-329. [PubMed: 953035]

47. Swaisgood HE, Abraham P. Oxygen Activation by Sulfhydryl Oxidase and the Enzyme's Interation with Peroxidase. J. Dairy Sci 1980;63:1205-1210. [PubMed: 7191433]

48. Lonnerdal B, Iyer S. Lactoferrin: molecular structure and biological function. Annu. Rev. Nutr 1995;15:93-110. [PubMed: 8527233]

49. Ward PP, Paz E, Conneely OM. Multifunctional roles of lactoferrin: a critical overview. Cell Mol. Life Sci 2005;62:2540-2548. [PubMed: 16261256]

50. Levay PF, Viljoen M. Lactoferrin: a general review. Haematologica 1995;80:252-267. [PubMed: 7672721]

51. Stumm, W.; Morgan, JJ. Aquatic Chemistry. 2nd ed.. John Wiley \& Sons Inc.; 1981.

52. Cotton, FA.; Wilkinson, GM.; Carlos, A.; Bochmann, M. Advanced Inorganic Chemistry. 6 th ed.. Wiley; 1999.

53. Hagihara B, Ishibashi F, Sasaki K, Kamigawara Y. Cellulose-Acetate Coatings for Polarographic Oxygen-Electrode. Anal. Biochem 1978;86:417-431. [PubMed: 655407]

54. Raje S, Thorpe C. Inter-domain redox communication in flavoenzymes of the quiescin/sulfhydryl oxidase family: role of a thioredoxin domain in disulfide bond formation. Biochemistry 2003;42:4560-4568. [PubMed: 12693953]

55. Wilcox CP, Janolino VG, Swaisgood HE. Isolation and partial characterization of CD36 from skim milk. J Dairy Sci 2002;85:1903-1908. [PubMed: 12214981]

56. Mather IH. A review and proposed nomenclature for major proteins of the milk-fat globule membrane. J Dairy Sci 2000;83:203-247. [PubMed: 10714856]

57. Kitchen BJ. A comparison of the properties of membranes isolated from bovine skim milk and cream. Biochim. Biophys. Acta 1974;356:257-269. [PubMed: 4152380]

58. Stewart PS, Puppione DL, Patton S. The presence of microvilli and other membrane fragments in the non-fat phase of bovine milk. Z. Zellforsch. Mikrosk. Anat 1972;123:161-167. [PubMed: 4332347]

59. Plantz PE, Patton S, Keenan TW. Further evidence of plasma membrane material in skim milk. J. Dairy Sci 1973;56:978-983. [PubMed: 4199911]

60. Isaacs, C. Methods in Human Lactation. Jensen, RG.; Neville, MC., editors. Plenum Press; Winter Park, CO: 1984. p. 277-282.

61. Mairet-Coello G, Tury A, Fellmann D, Risold PY, Griffond B. Ontogenesis of the sulfhydryl oxidase QSOX expression in rat brain. J. Comp. Neurol 2005;484:403-417. [PubMed: 15770657]

62. Chakravarthi S, Jessop CE, Willer M, Stirling CJ, Bulleid NJ. Intracellular catalysis of disulphide bond formation by the human sulphydryl oxidase, QSOX1. Biochem J 2007;404:403-411. [PubMed: 17331072]

63. Kelly VC, Kuy S, Palmer DJ, Xu Z, Davis SR, Cooper GJ. Characterization of bovine seminal plasma by proteomics. Proteomics 2006;6:5826-5833. [PubMed: 17001600]

64. Mairet-Coello G, Tury A, Esnard-Feve A, Fellmann D, Risold PY, Griffond B. FAD-linked sulfhydryl oxidase QSOX: topographic, cellular, and subcellular immunolocalization in adult rat central nervous system. J. Comp. Neurol 2004;473:334-363. [PubMed: 15116395]

65. Isaacs CE, Pascal T, Wright CE, Gaull GE. Sulfhydryl oxidase in human milk: stability of milk enzymes in the gastrointestinal tract. Pediatr. Res 1984;18:532-535. [PubMed: 6146124]

66. Matsuba S, Suga Y, Ishidoh K, Hashimoto Y, Takamori K, Kominami E, Wilhelm B, Seitz J, Ogawa H. Sulfhydryl oxidase (SOx) from mouse epidermis: molecular cloning, nucleotide sequence, and expression of recombinant protein in the cultured cells. J Dermatol Sci 2002;30:50-62. [PubMed: 12354420] 
67. Kall L, Krogh A, Sonnhammer EL. Advantages of combined transmembrane topology and signal peptide prediction--the Phobius web server. Nucleic Acids Res 2007:W429-432. [PubMed: $17483518]$

68. Thompson JD, Higgins DG, Gibson TJ. Clustal-W - Improving the Sensitivity of Progressive Multiple Sequence Alignment through Sequence Weighting, Position-Specific Gap Penalties and Weight Matrix Choice. Nucleic Acids Res 1994;22:4673-4680. [PubMed: 7984417] 


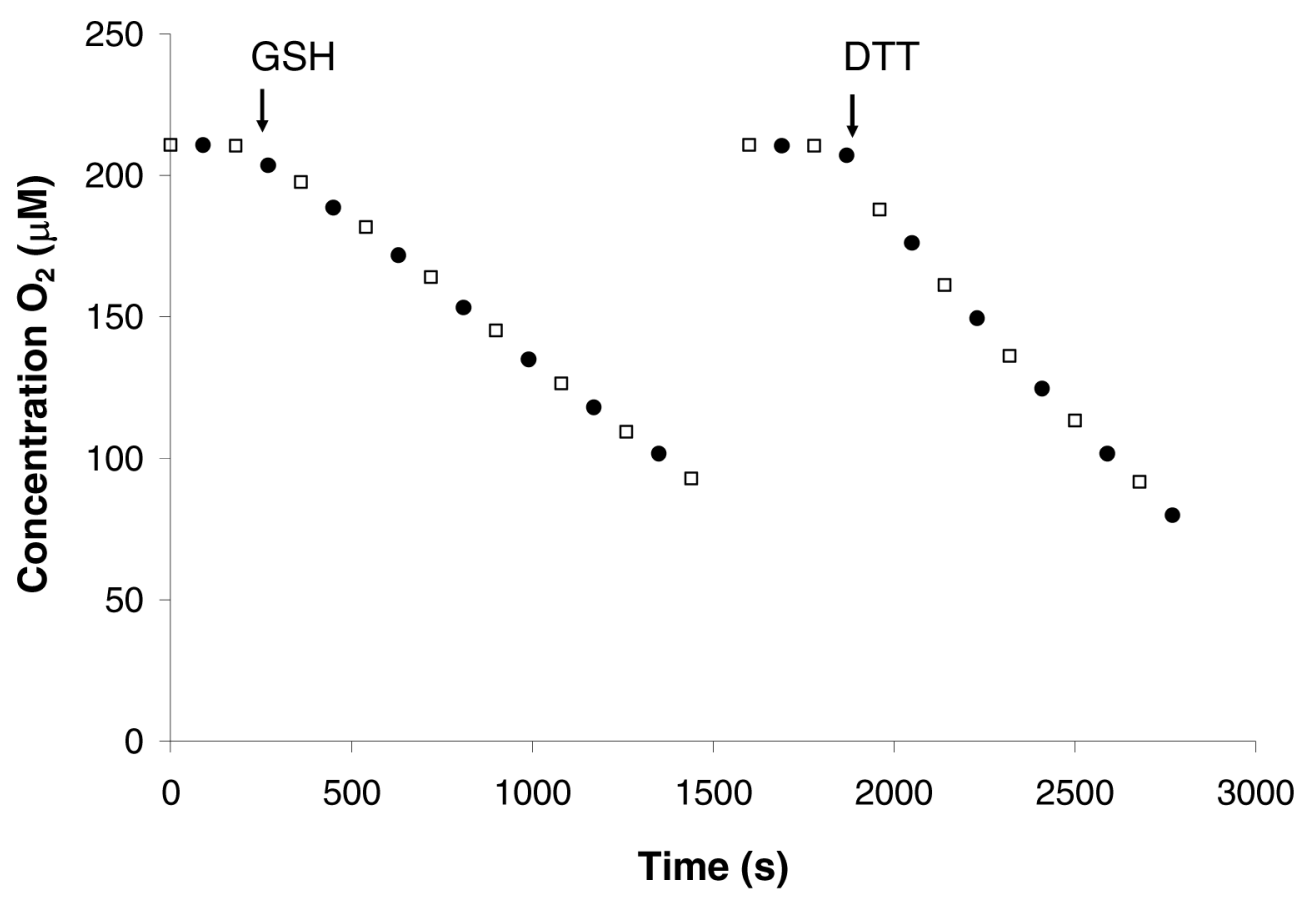

FIGURE 1.

Oxygen electrode assays of skim milk for sulfhydryl oxidase activity using glutathione and DTT as substrates. Assays contained $1 \mathrm{~mL}$ of skim milk and $1 \mathrm{~mL}$ of $50 \mathrm{mM}$ phosphate buffer with (circles) or without (squares) $1 \mathrm{mM}$ EDTA. At the arrows, assays were started by the addition of $5 \mathrm{mM}$ GSH (see Methods, left panel) or DTT (right panel). 

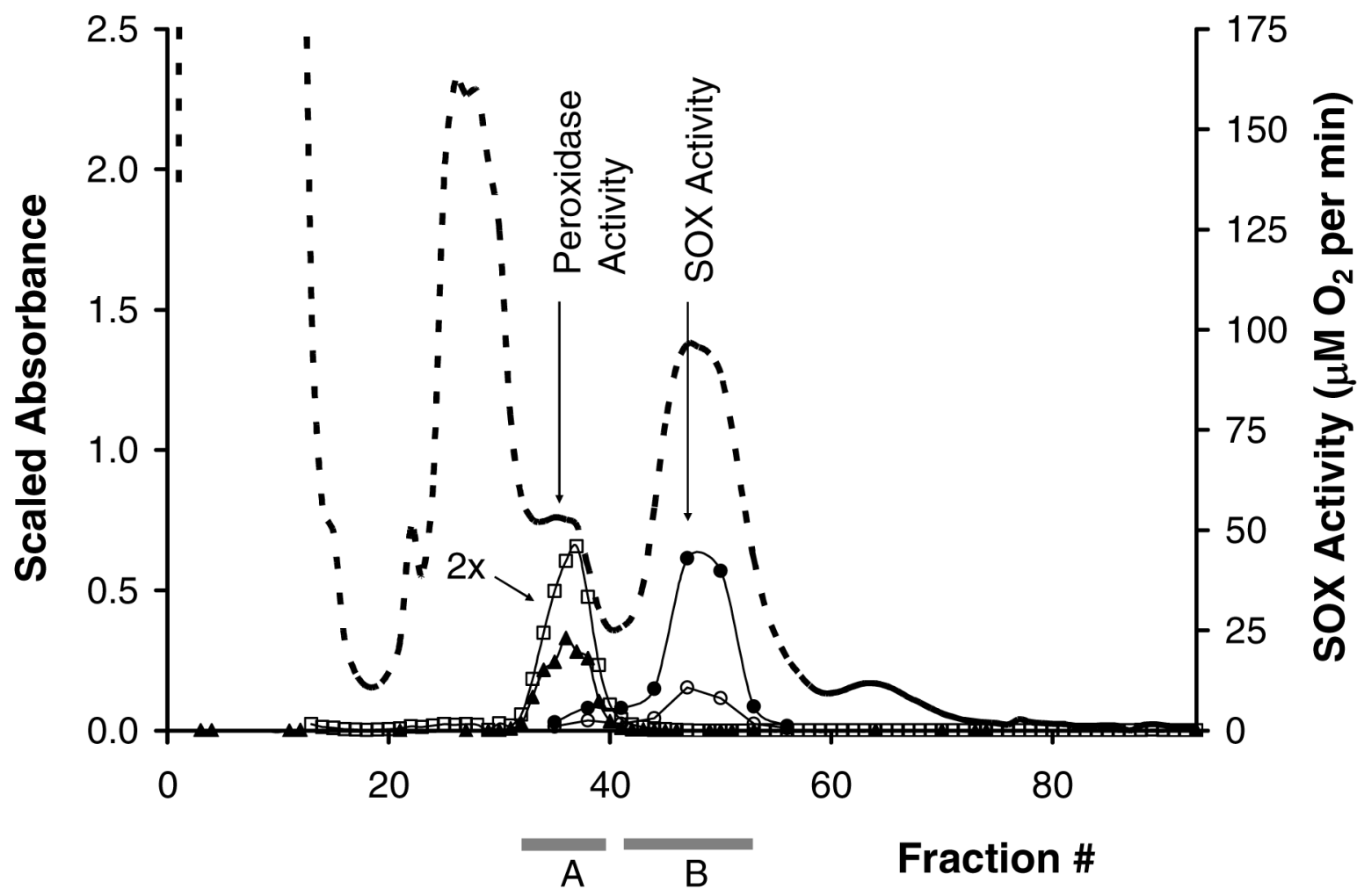

FIGURE 2.

Cation-exchange chromatography (CM52) of skim milk membranes at $\mathrm{pH}$ 6.0. The dashed line indicates absorbance at $280 \mathrm{~nm}$ with contribution from turbidity (fraction 1-15). Solid and open circles represent DTT and GSH oxidase activity respectively, squares Soret absorbance at 415 $\mathrm{nm}$, and triangles, peroxidase activity (see Methods). Absorbance values at $415 \mathrm{~nm}$ for fractions 1-12 are not included because these initial fractions were turbid. The column was developed with a gradient of $0-1.0 \mathrm{M} \mathrm{KCl}$ in $20 \mathrm{mM}$ phosphate buffer, $\mathrm{pH}$ 6.0. 


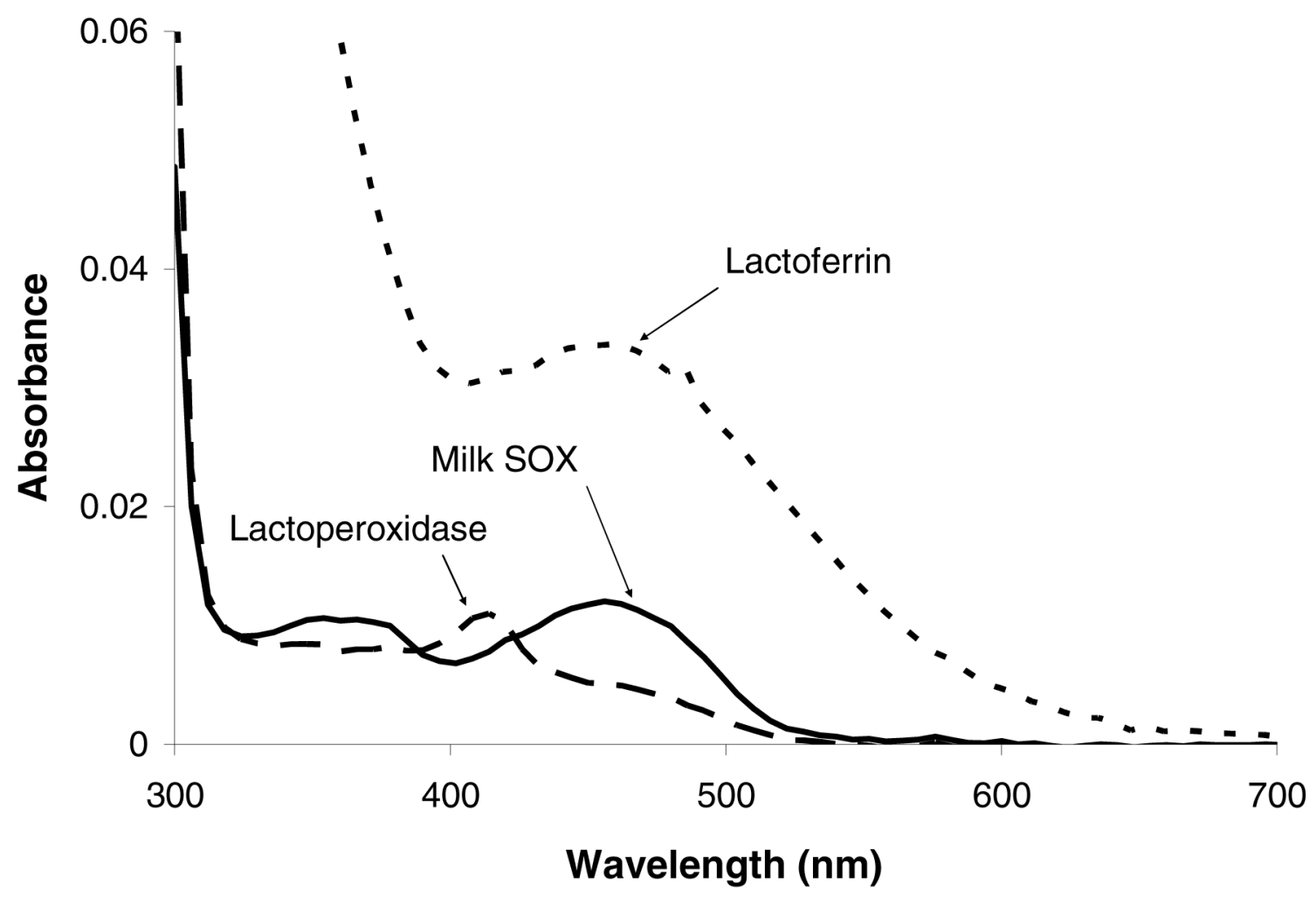

FIGURE 3.

Visible spectra of three species eluting from butyl-Sepharose hydrophobic interaction chromatography. Spectra of fractions 16 (lactoferrin), 19 (lactoperoxidase) and 22 (sulfhydryl oxidase) were recorded without dilution and were adjusted to zero at $800 \mathrm{~nm}$ to correct for small levels of light scattering between samples. 


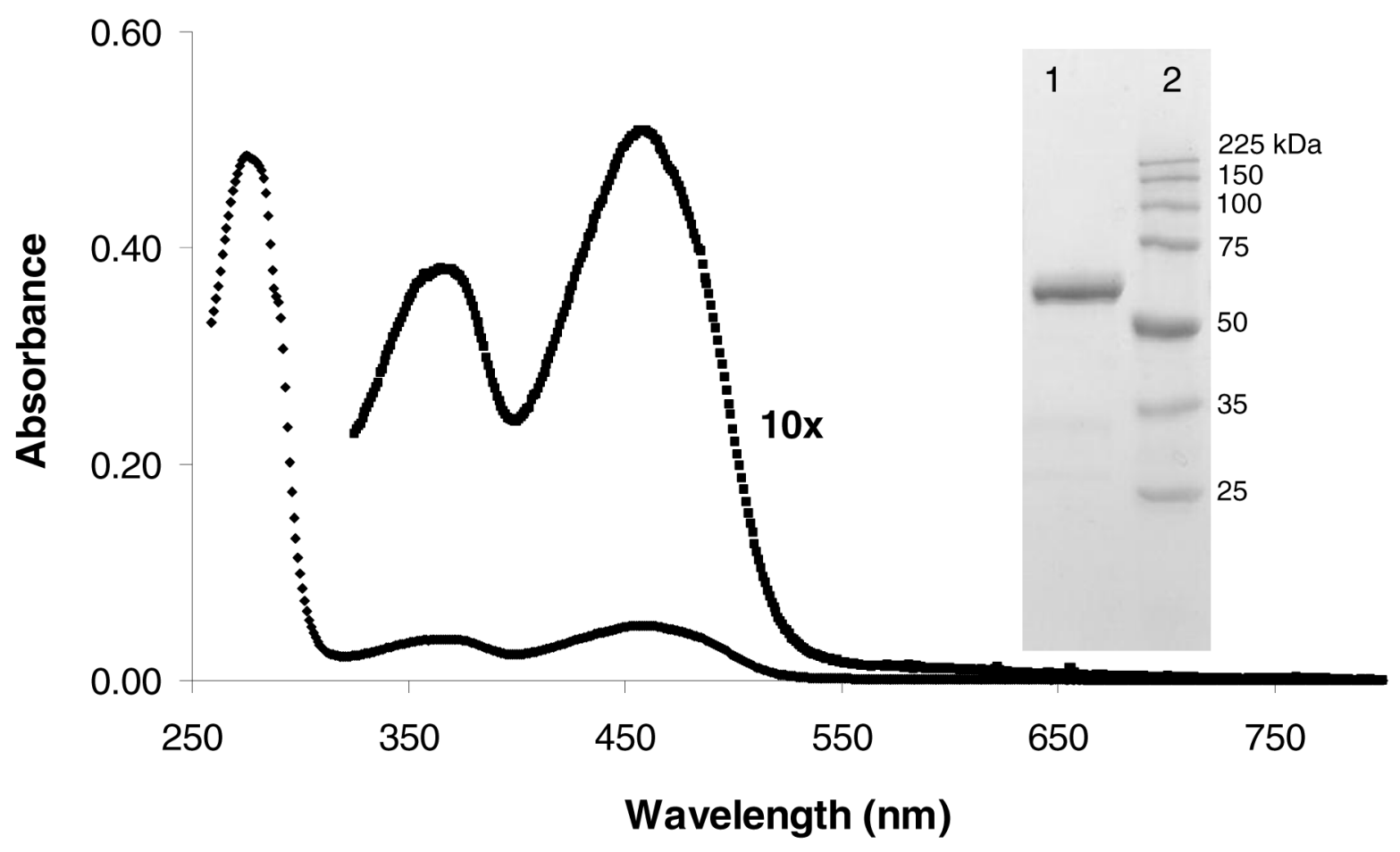

FIGURE 4.

UV/VIS spectrum of purified milk sulfhydryl oxidase. Spectra were recorded in $50 \mathrm{mM}$ phosphate buffer, $\mathrm{pH} 7.5$, containing $1 \mathrm{mM}$ EDTA. The 280/458 nm ratio was 9.4. A 10 -fold amplification of the absorbance in the visible region highlights the spectrum of bound flavin. Lanes 1 and 2 in the inset show separation of the purified enzyme by reducing SDS-PAGE and a mixture of protein molecular weight markers, respectively. 

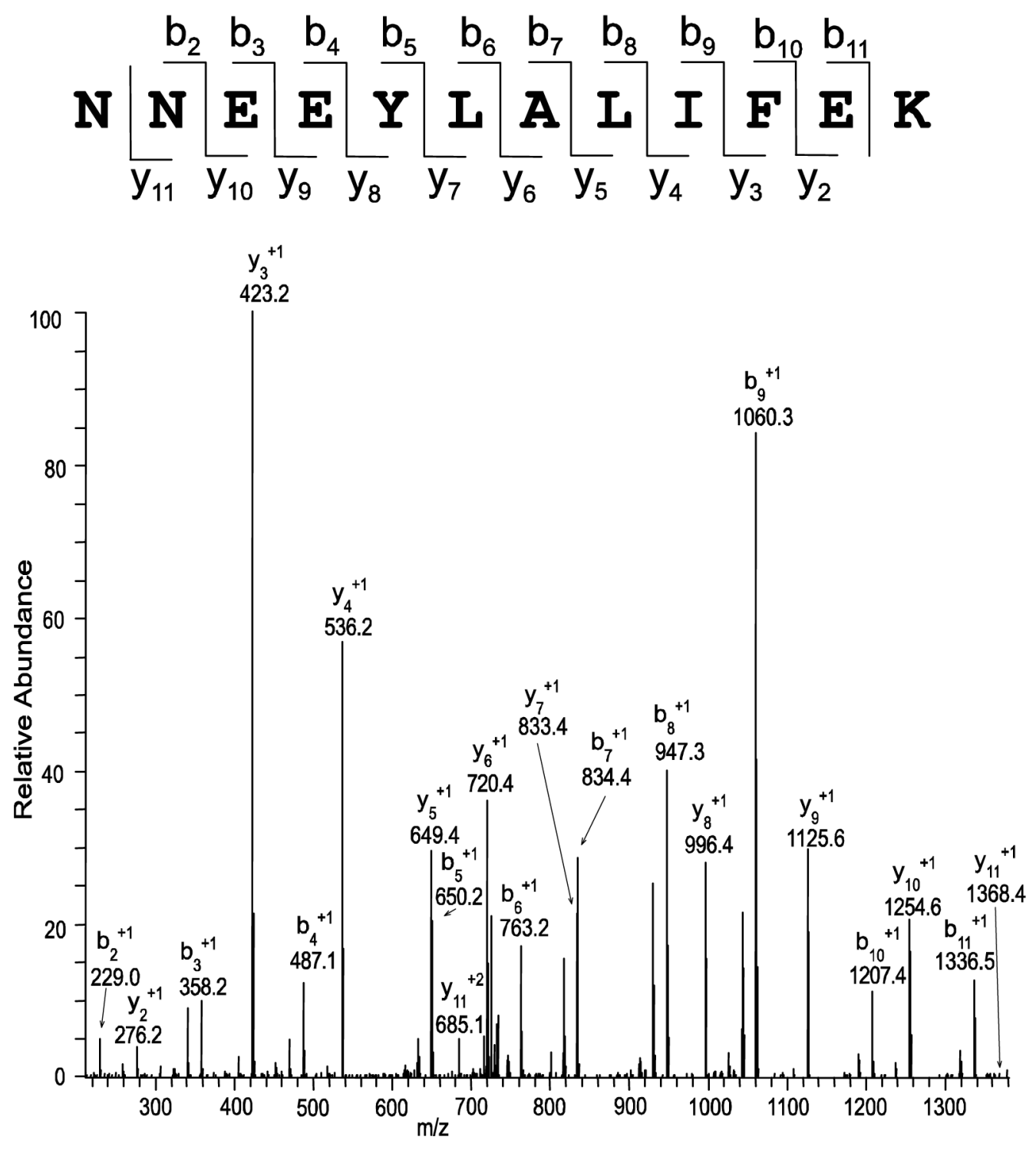

FIGURE 5.

Example spectrum obtained for the peptide sequence ${ }^{184}$ NNEEYLALIFEK ${ }^{195}$ from the identification of bovine QSOX 1 by LC-MS/MS. Peptides were produced by in-gel tryptic digestion and analyzed by LC-MS/MS as described in Methods and in Supplementary Materials. Sequences were searched against a bovine database (see the Text). In addition to the complete series of $+1 \mathrm{~b}$ - and y-ions, a complete set of $+1 \mathrm{~b}-\mathrm{NH}_{3}$ ions may also be observed $17 \mathrm{amu}$ to the left of the $+1 \mathrm{~b}_{3}-\mathrm{b}_{11}$ ions. 
121 TVRFFKAFSK TGSGTTLSVA GADVQTLRER LIDALESHSD TWPPACPPLE PARLEEITGF

181 FARNNEEYLA LIFEKEGSYL GREVTLDLSQ HQGIAVRRVL NTERDVVNRF GVTNFPSCYL

241 LSRNGSFSRV PALTESRSFY TTYLRKFSGS TRGAVQTTAA PATTSAVAPT VWKVADRSKI

301 YMADLESALH YILRIEVGKF SVLEGQRLVA LKKFMAVLAK YFRGRPLVQN FLHSMNDWLK

361 KQQRKKIPYG FFKNALDSRK EGTVIAEKVN WVGCQGSEPH FRGFPCSLWI LFHFLTVQAA

421 QEGVDHPQER AKAQEVLQAI RGYVRFFFGC RECAGHFEQM ASGSMHRVGS LNSAVLWFWS

481 SHNKVNARLA GAPSEDPQFP KVQWPPRELC SACHNELRGT PVWDLDNILK FLKTHFSPSN

541 IVLDFPSAGP GPWRGAERMA VIPKQVELEL ATGNVTLAPE KAEIPVGSGI KAPGGTIPVA

601 GLGANHPKMQ AGLGAATDEP DPGAPEHVVE LHRDKSKQPE REQRLSRRDT GAVLLAEFLA

661 GRNLPGGPSE LGRVGRSSQQ LAGIPDREPE AGAGQGQGQW LQMLGGNFSH LDISLCVGLY

721 SLSFMGLLAV YTYFRARIRA LKGYASLPTA

FIGURE 6.

Full length sequence of bovine QSOX1 and placement of peptides therein. The N-terminal region (residues 1-90) corresponds to IPI00704610 version 3.04. The remaining sequence corresponds to NCBI XP_601276 (see Supplemental Material). Peptide sequence coverage is shown underlined. Each peptide sequenced is detailed in Supplementary Table 1. Assuming a molecular weight for the mature protein of $62 \mathrm{kDa}$ (with a start at residue 31 (prediction using Phobius (67)) implies a C-terminus close to residue 590 (corresponding to a sequence coverage of approximately $72 \%$ ). The three conserved $\mathrm{CxxC}$ motifs are highlighted in red and three domains of known structure are shown in blue (Trx1), light blue (Trx2), and green (ERV/ALR). The putative signal sequence, and the C-terminal transmembrane span of the long form of QSOX1, are shown in orange and grey respectively (prediction using Phobius (67)). A plain text version of this complete sequence is presented as Supplementary Figure S3). 


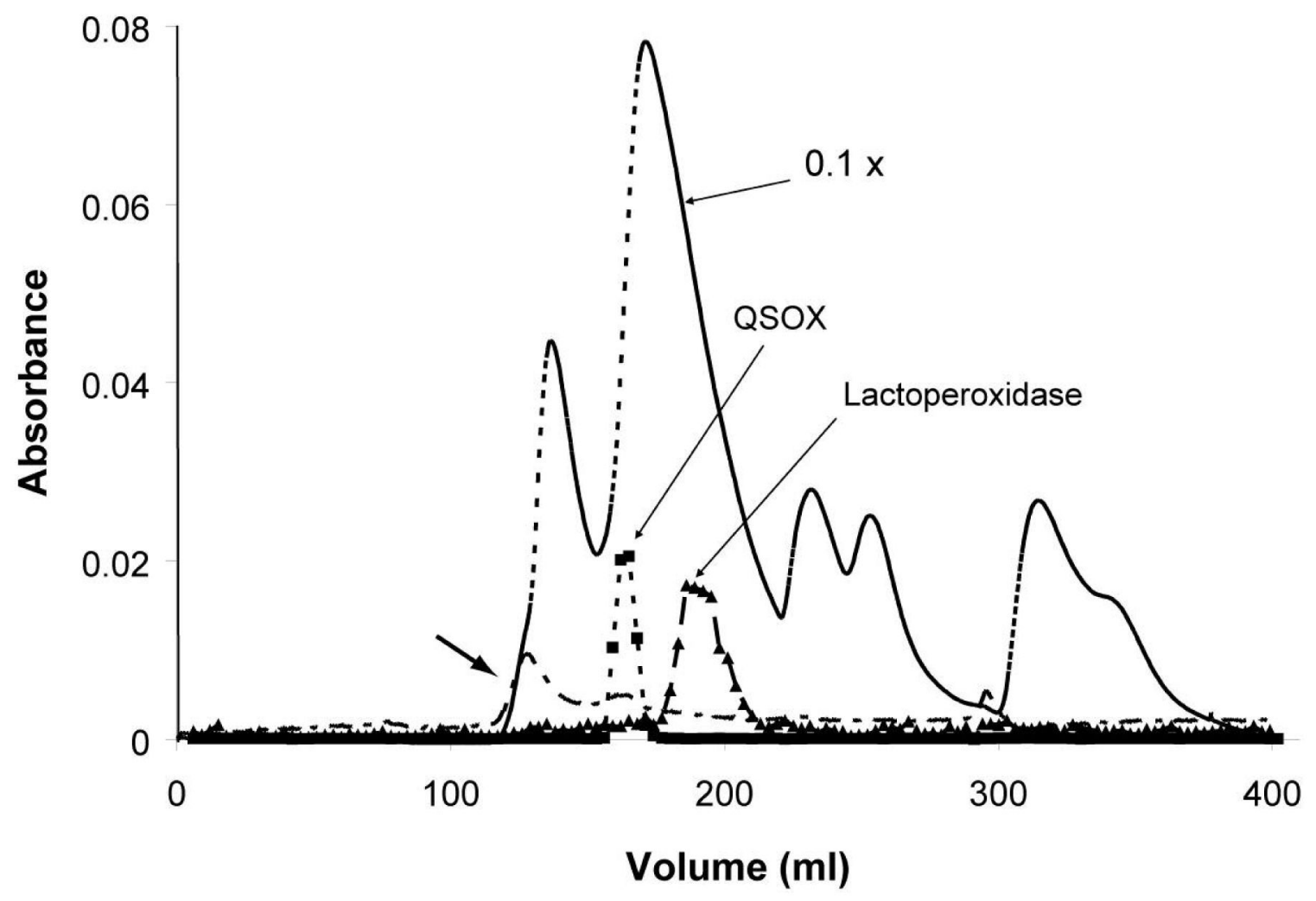

FIGURE 7.

Gel filtration exclusion elution profiles of skim milk. A $3.0 \times 70 \mathrm{~cm}$ Superdex 200 column was loaded with $2 \mathrm{~mL}$ of freshly prepared skim milk and developed at $22{ }^{\circ} \mathrm{C}$ in $50 \mathrm{mM}$ phosphate buffer with $1 \mathrm{mM}$ EDTA. Light scattering material (followed at $700 \mathrm{~nm}$, dash-dot line), including membrane fragments, elute in the void volume of the column at the bold arrow. Sulfhydryl oxidase and lactoperoxidase levels in each fraction were assessed as in Methods. Absorbance values were scaled by the factors shown for each curve (e.g. the peak $280 \mathrm{~nm}$ absorbance value at $170 \mathrm{~mL}$ was 0.78 ). Assays values for QSOX and lactoperoxidase were scaled by 0.0067 and 0.125 times respectively. 


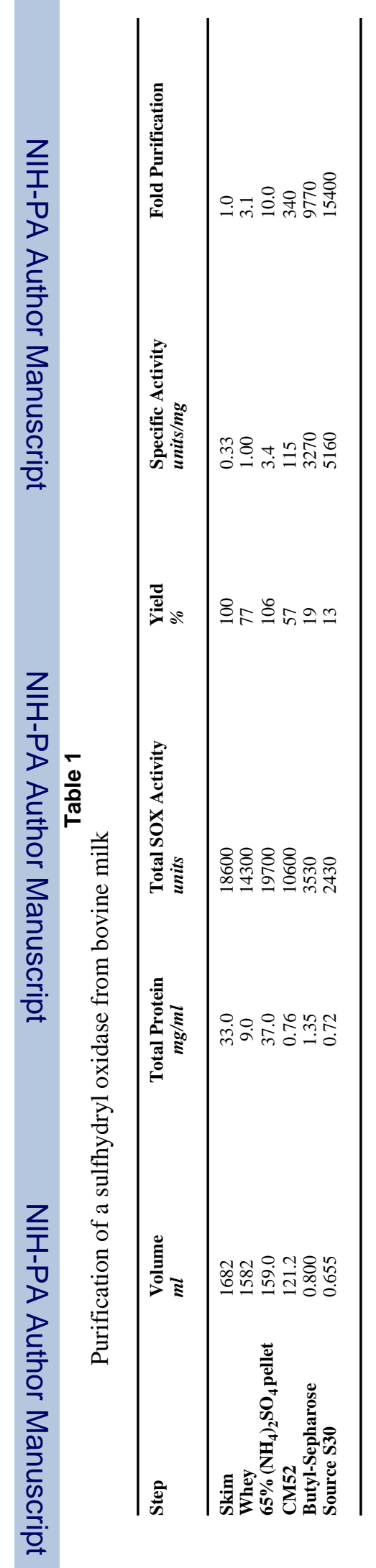

Biochemistry. Author manuscript; available in PMC 2008 November 13. 
Table 2

Pairwise sequence alignments of selected QSOXs to bovine milk QSOX1 ${ }^{a}$

\begin{tabular}{|c|c|c|}
\hline Organism & QSOX 1 & QSOX 2 \\
\hline $\begin{array}{l}\text { Bos taurus } \\
\text { Homo sapiens } \\
\text { Mus musculus } \\
\text { Gallus gallus }\end{array}$ & $\begin{array}{l}100 \\
76 \\
74 \\
46\end{array}$ & $\begin{array}{l}- \\
36 \\
37 \\
37\end{array}$ \\
\hline
\end{tabular}

${ }^{a}$ Alignments were performed using the ClustalW program (68). The bovine QSOX2 sequence is currently unavailable. 


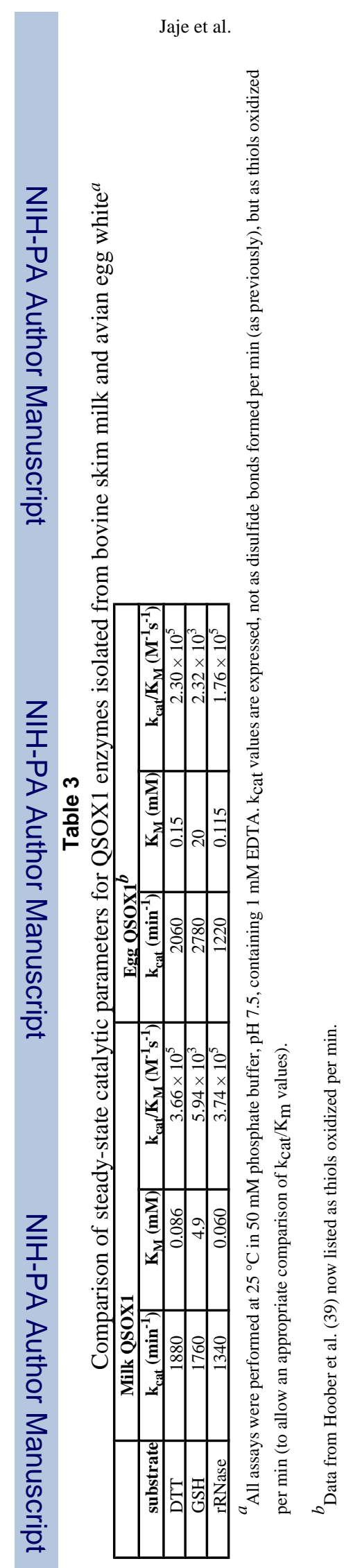

Biochemistry. Author manuscript; available in PMC 2008 November 13. 